\title{
Correlation Between Perfusion Abnormalities Extent in Ventilation/ Perfusion SPECT/CT with Hemodynamic Parameters in Patients with Chronic Thromboembolic Pulmonary Hypertension
}

\author{
Kronik Tromboembolik Pulmoner Hipertansiyonlu Hastalarda Ventilasyon/Perfüzyon \\ SPECT/BT'de Saptanan Perfüzyon Defekti Yaygınlığı ile Hemodinamik Parametreler \\ Arasındaki Ilişki

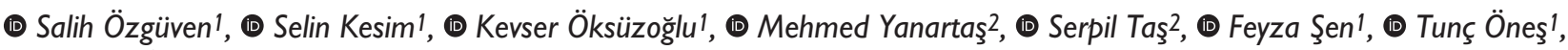 \\ (1) Sabahat İnanır', (1) Halil Turgut Turoğlu', (1) Bülent Mutlu³, (1) Tanju Yusuf Erdil', (1) Bedrettin Yıldızeli4 \\ IMarmara University Pendik Training and Research Hospital, Clinic of Nuclear Medicine, Istanbul, Turkey \\ 2University of Health Sciences Turkey, Kartal Koşuyolu Training and Research Hospital, Clinic of Cardiovascular Surgery, Istanbul, Turkey \\ 3 Marmara University Pendik Training and Research Hospital, Clinic of Cardiology, Istanbul, Turkey \\ 4 Marmara University Pendik Training and Research Hospital, Clinic of Thoracic Surgery, Istanbul, Turkey
}

\begin{abstract}
Objectives: Chronic thromboembolic pulmonary hypertension (CTEPH) is a type of pulmonary hypertension with persistent pulmonary vascular obstruction and exercise intolerance, which may benefit from pulmonary endarterectomy (PEA). Ventilation/perfusion (V/Q) scan is the preferred screening test of CTEPH, which can be used to assess the anatomical extent of the disease. This study aimed to analyze the correlation between the extent of mismatched Q defects in V/Q single photon emission computed tomography/computed tomography (SPECT/CT) with preoperative clinical and hemodynamic parameters in patients with CTEPH.

Methods: A total of 102 patients with CTEPH prior to PEA having V/Q SPECT/CT scans were retrospectively reviewed. Age, gender, New York Heart Association classification, intraoperative right-sided heart catheterization (mPAP and PVR), and 6-minute walk test (6MWT) findings were obtained from clinical records of patients.

Results: Linear regression analysis showed a significant but weak correlation between the preoperative mPAP and PVR with the extent of mismatched $Q$ defects in V/Q SPECT/CT ( $r s=0.09474$ with $p=0.0016$ and $r s=0.045$ with $p=0.045$, respectively). No significant correlation was found between 6MWT and extent of mismatched Q defects in V/Q SPECT/CT ( $p>0.05)$.

Conclusion: A quantitative assessment of Q defects on V/Q SPECT/CT might provide information about hemodynamic parameters in patients with CTEPH.

Keywords: Chronic thromboembolic pulmonary hypertension, ventilation/perfusion scintigraphy, mean pulmonary arterial pressure, pulmonary vascular resistance, 6-minute walk distance
\end{abstract}

\section{Öz}

Amaç: Kronik tromboembolik pulmoner hipertansiyon (KTEPH), kalıı pulmoner vasküler obstrüksiyon ve egzersiz intoleransı ile karakterize bir pulmoner hipertansiyon grubudur ve pulmoner endarterektomiden (PEA) fayda görebilir. Ventilasyon/perfüzyon (V/Q) sintigrafisi, hastalı̆ı̆n

Address for Correspondence: Salih Özgüven MD, Marmara University Pendik Training and Research Hospital, Clinic of Nuclear Medicine, İstanbul, Turkey Phone: +90 5322511769 E-mail: drsozg@gmail.com ORCID ID: orcid.org/0000-0002-2790-7206 Received: 26.11.2020 Accepted: 15.12.2020 
anatomik yaygınlı̆ını değerlendirmek için kullanılabilen KTEPH'nin tercih edilen tarama testidir. Bu çalışmanın amacı, KTEPH tanılı hastalarda ameliyat öncesi klinik ve hemodinamik parametreler ile V/Q tek foton emisyon tomografisi/bilgisayarlı tomografideki (SPECT/BT) Q defektlerinin yaygınlığı arasındaki korelasyonu araştırmaktır.

Yöntem: PEA ile tanısı doğrulanmış 102 KTEPH hastasının PEA öncesi V/Q SPECT/BT görüntüleri retrospektif olarak incelendi. PEA öncesi yaş, cinsiyet, New York Kalp Derneği sınıfı, intraoperatif sağ kalp kateterizasyonu sonuçları [ortalama pulmoner arter basıncı (OPAB), pulmoner vasküler rezistans (PVR)] ve 6 dakikalık yürüme testi (6DYT) gibi klinik parametreleri hastaların klinik kayıtlarından elde edildi.

Bulgular: Doğrusal regresyon analizi, preoperative OPAB ve PVR ile V/Q SPECT/BT'deki eşleşmeyen Q defektlerinin yaygınlığı ile anlamlı ancak zayıf bir korelasyon gösterdi ( $r s=0,09474, p=0,0016 ; r s=0,045, p=0,045)$. 6 DYT mesafesi ile eşleşmeyen Q defektlerinin yaygınlığı arasında ise anlamlı bir ilişki bulunmadı $(p>0,05)$.

Sonuç: V/Q SPECT/BT'de saptanan Q defektlerinin kantitatif değerlendirilmesi, KTEPH tanılı hastalarda hemodinamik parametreler hakkında fikir sağlayabilir.

Anahtar kelimeler: Kronik tromboembolik pulmoner hipertansiyon, ventilasyon/perfüzyon sintigrafisi, ortalama pulmoner arter basıncı, pulmoner vasküler direnç, 6 dakikalık yürüme testi

\section{Introduction}

Chronic thromboembolic pulmonary hypertension (CTEPH) is a progressive pre-capillary pulmonary hypertension, which results from incomplete resolution of a pulmonary embolus, leading to elevated pulmonary vascular resistance (PVR), mean pulmonary artery pressure (mPAP), and rightsided heart failure $(1,2)$. Acute embolism can vary from a total resolution to persistent perfusion $(\mathrm{Q})$ defects after an adequate anticoagulation therapy. Approximately, $30 \%$ of patients have permanent defects after 6 months of anticoagulation; however, only $10 \%$ of defects consequently developed CTEPH (3).

CTEPH should be questioned in patients with abnormal ventilation (V)/Q scintigraphy including at least one mismatched segmental $\mathrm{Q}$ defect and imaging findings of organized thrombi in pulmonary arteries following $>3$ months of therapeutic anticoagulation (3). Invasive pulmonary angiography historically remains as the objective reference standard for diagnosis and evaluation for chronic emboli extent, whereas V/Q scan is the preferred first-line screening test for CTEPH $(4,5)$. V/Q scintigraphy is used to diagnose and assess the anatomical extension of mold, and estimate therapy response in patients with CTEPH (6). The only curative treatment option for CTEPH is the pulmonary endarterectomy (PEA) in appropriate patients (7). This technique is associated with improved survival, functional capacity, and quality of life $(1,8)$. PEA may be related with high mortality rates regarding to the extent of the disease $(9,10)$.

Factors that need to be assessed before PEA include the anatomical location and distribution of disease and left and right ventricular systolic functions (6). Previous studies showed that hemodynamic parameters play a crucial part in the evaluation of prognosis, disease severity, and operability $(11,12)$. This study aimed to assess the association of the extent of mismatched Q abnormalities in V/Q single photon emission computed tomography/computed tomography (SPECT/CT) with preoperative hemodynamic and clinical parameters in patients with CTEPH.

\section{Materials and Methods}

\section{Study Subjects}

Over a period of nine years (January 2011 to May 2020), a total of 677 patients with a diagnosis of CTEPH at the preoperative evaluation underwent PEA. Of which, 102 patients with CTEPH whose V/Q SPECT/CT images obtained in our clinic prior to PEA were retrospectively reviewed.

Study exclusion incudes patients with isolated pulmonary artery vasculitis $(n=8)$, hydatid cyst $(n=8)$, pulmonary artery sarcomas $(n=9)$, no mismatched V/Q defects in scintigraphy $(n=7)$, and whose preoperative $V / Q$ scans not acquired in our institution or lacking in our database $(n=543)$.

Age, gender, New York Heart Association (NYHA) classification, intraoperative right-sided heart catheterization (RHC) (mPAP and PVR), and 6-minute walk test (6MWT) findings were obtained from clinical records of patients.

An informed consent was taken from all patients before the examination. Marmara University Faculty of Medicine Clinical Studies Ethics Committee approval was also obtained (date: September 2020, no: 09.2020.852).

\section{V/Q SPECT/CT Protocol}

V/Q scans were performed with a one-day protocol (13). The V SPECT images were obtained before the Q scan. A 12-15 millicurie (444-555 megabecquerel) technetium-99m (Tc-99m)-Technegas generated by the "TechnegasPlus" generator device (Cyclomedica Australia Pty Ltd., Australia) was used for the $V$ phase. SPECT images of patients using a $180^{\circ}$ dual head detector on SPECT/CT (Siemens Symbia TruePoint, Siemens Medical Solutions, USA) were 
acquired. Afterward, a Q SPECT with low dose CT scans was immediately obtained on the same table. After a slow (within 20-30 s) injection of 4-5 millicurie (148-185 megabecquerel). Tc-99m-macro aggregated albumin, (TechneScan LyoMAA; Mallinckrodt Medical) containing $100,000-200,000$ particles, SPECT/CT was taken on the same device using similar SPECT parameters as those used for the $V$ phase (low-energy high-resolution collimator, $128 \times 128$ matrix, 64 projections of $10 \mathrm{~s}, 1.00$ zoom factor, and $140 \pm 10 \%$ keV energy window) and $13-25 \mathrm{mAs}, 130 \mathrm{kV}$, and slice width of $5 \mathrm{~mm}$ for CT. Raw data of SPECT images processed with the "Tomo Reconstruction v.8.2.26.4" (Syngo-Siemens AG) application and reconstruction was conducted with ordered subset expectation maximization method.

\section{Image Analysis}

V/Q SPECT/CT images were evaluated by two nuclear medicine physicians without knowledge of the preoperative hemodynamic parameters and 6MVT records of patients. To figure out CTEPH severity, V/Q images were analyzed together for each pulmonary segment (14). Two physicians discussed each case to reach a final consensus.

\section{Clinical Data Analysis}

RHC protocol and 6MWT protocol was carried out in accordance with previously described standard procedures $(15,16,17)$. Data of the RHC (mPAP and PVR) and 6MWT were obtained from the clinical records of patients.

\section{Statistical Analysis}

For continuous variables a mean value \pm standard deviation and for categorical variables number and percentage were calculated. Per-segment basis analysis for each patient was used to estimate disease severity. Linear regression analysis was conducted to examine the concordance of mismatched Q defects severity on V/Q SPECT/CT with RHC and $6 \mathrm{MWT}$ results. Data analysis and graphs were plotted using GraphPad Prism version 8.0 for macOS, GraphPad Software, La Jolla California USA. P values of 0.05 or less were regarded as significant.

\section{Results}

A statistical analysis of 102 patients with a diagnosis of CTEPH is presented, wherein 46 patients $(45.1 \%)$ were women and 56 patients (54.9\%) were men. The mean age of patients was 51.66 years (range of 19-77 years and standard deviation of 15.95). A total of 11 patients (10.8\%) were NYHA class II, 74 patients $(72.5 \%)$ were NYHA class III, and 17 patients (16.6\%) were NYHA class IV. The mean preoperative mPAP and mean preoperative
PVR were $43.73 \pm 14.77 \mathrm{mmHg}$ and $681.62 \pm 411.75$ dyn $\cdot \mathrm{s} \cdot \mathrm{cm}^{-5}$, respectively. The mean $6 \mathrm{MWT}$ distance was $334.40 \pm 113.62$ meters. The average number of abnormally perfused segments was $12.84 \pm 5.30$

The linear regression analysis showed a significant but weak correlation between the preoperative MPAP and PVR with the extent of mismatched Q defects in V/Q SPECT/CT $(r s=0.09474$ with $p=0.0016$ and $r s=0.045$ with $p=0.045$, respectively) (Figure 1, 2).

No significant correlation was found between 6MWT distance and extent of the mismatched $\mathrm{Q}$ defects in $\mathrm{V} / \mathrm{Q}$ SPECT/CT ( $p>0.05$ ) (Figure 3).

\section{Discussion}

The correlation of the degree of persistent thromboembolic disease (mismatched $\mathrm{Q}$ defects in $\mathrm{V} / \mathrm{Q}$ $\mathrm{SPECT} / \mathrm{CT}$ ) with preoperative clinical and hemodynamic parameters was examined in the present research with the greatest number of patients with CTEPH proven by post-PEA surgical histopathological examinations. Results showed a statistically significant correlation between the number of mismatched Q defects in V/Q SPECT/CT and preoperative mPAP and PVR, but not with 6MVT. PVR and MPAP are the essential hemodynamic parameters in patients with CTEPH. Increased PVR is mainly caused by endothelial dysfunction, vasoconstriction, vascular remodeling, and obstruction of small pulmonary arteries. Interleukin-1 (IL-1), IL-6, and tumor necrosis factor-a are

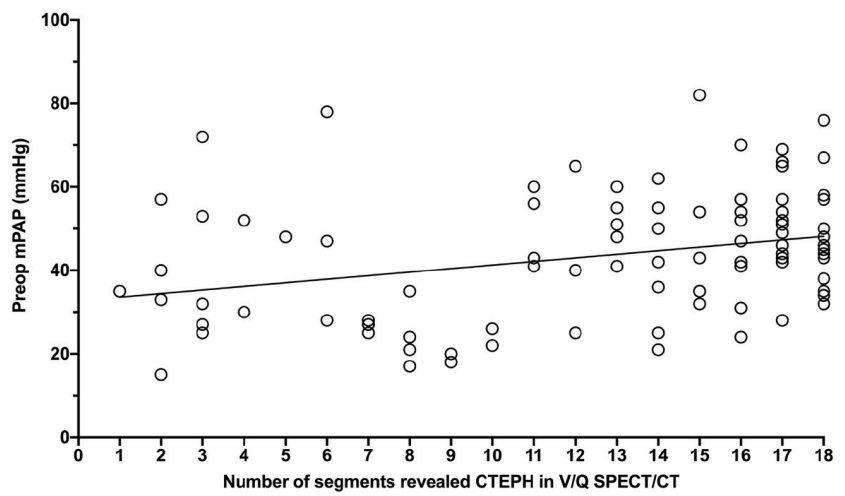

Figure 1. Correlation between preoperative mean pulmonary arterial pressure (mPAP) levels and number of segments revealed in chronic thromboembolic pulmonary hypertension ventilation/perfusion single photon emission computed tomography/computed tomography (V/Q SPECT/CT). Application of linear regression analysis revealed a significant but weak correlation between the preoperative MPAP and extent of mismatched perfusion defects in V/Q SPECT/CT ( $r s=0.09474$ and $\mathrm{p}=0.0016$ )

CTEPH: Chronic thromboembolic pulmonary hypertension, mPAP: Mean pulmonary arterial pressure, V/Q: Ventilation/perfusion, SPECT/CT: Single photon emission computed tomography/computed tomography 
pro-inflammatory cytokines that are relevant to the pathogenesis (18). Dartevelle et al. (19) reported higher mortality rates for patients with PVR $>900$ dyn $\cdot \mathrm{s} \cdot \mathrm{cm}^{-5}$ than those with PVR $<900 \mathrm{dyn} \cdot \mathrm{s} \cdot \mathrm{cm}^{-5}$. Furthermore, no patients with PVR $<300 \mathrm{dyn} \cdot \mathrm{s} \cdot \mathrm{cm}^{-5}$ pre-operatively died after PEA in a study performed by Yıldızeli et al. (17). In addition, increased mPAP, which induces right ventricular dysfunction, is found to be associated with higher mortality (20). In a study by Saouti et al. (21), the risk

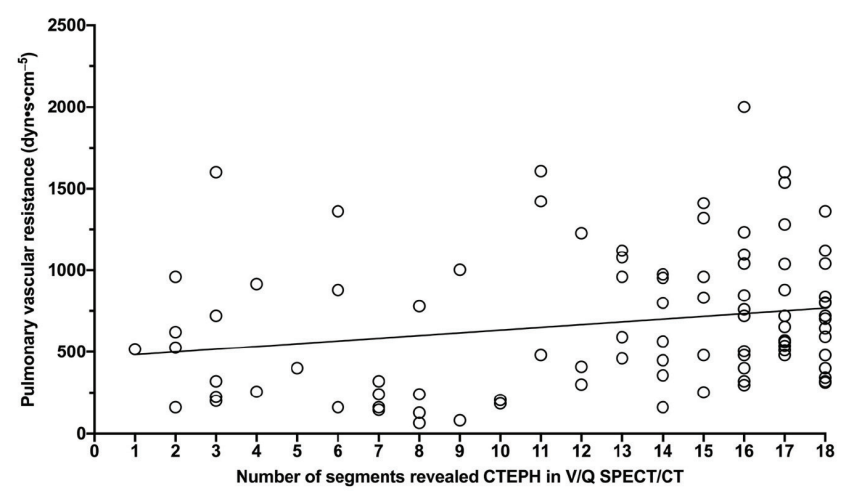

Figure 2. Correlation between preoperative pulmonary vascular resistance (PVR) and number of segments revealed in chronic thromboembolic pulmonary hypertension ventilation/perfusion (V/Q) single photon emission computed tomography/computed tomography (SPECT/CT). Linear regression analysis showed a significant but weak correlation between the preoperative PVR and extent of mismatched perfusion defects in V/Q SPECT/CT ( $r s=0.045$ and $p=0.045$ )

CTEPH: Chronic thromboembolic pulmonary hypertension, V/Q: Ventilation/ perfusion, SPECT/CT: Single photon emission computed tomography/computed tomography

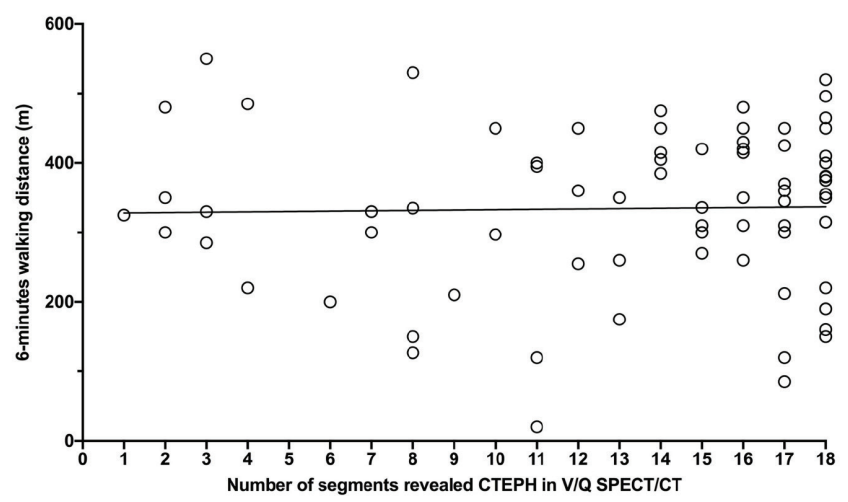

Figure 3. Correlation between 6-minutes walking distance and number of segments revealed in chronic thromboembolic pulmonary hypertension ventilation/perfusion (V/Q) single photon emission computed tomography/computed tomography (SPECT/CT). No significant correlation was found between 6-minute walk distance and extent of mismatched perfusion defects in V/Q SPECT/CT $(p>0.05)$

CTEPH: Chronic thromboembolic pulmonary hypertension, V/Q: Ventilation/ perfusion, SPECT/CT: Single photon emission computed tomography/computed tomography of mortality is higher in patients with mPAP $>40 \mathrm{mmHg}$ than those with an mPAP $<40 \mathrm{mmHg}$. The association between the extent of the disease and hemodynamic parameters has been described in literature (22). Fukuchi et al. (23) found a correlation between planar Q index with MPAP and right ventricular ejection fraction using planar pulmonary Q scintigraphy. Recently, Derlin and colleagues, who investigated the correlation between $\mathrm{V} / \mathrm{Q}$ SPECT/CT imaging findings and RHC, showed a statistically significant association between $Q$ defect score, perfused lung volume, $Q$ index with mPAP, and PVR (24). In line with other studies, a statistically significant difference between mismatched $\mathrm{Q}$ defects in $\mathrm{V} / \mathrm{Q}$ SPECT/CT and preoperative MPAP ( $\mathrm{rs}=0.095$ and $p=0.0016)$ and PVR ( $r s=0.045$ and $p=0.035)$ values was observed.

Patients with CTEPH generally display a decreased exercise capacity that is most commonly assessed with 6MVT. The prognostic value of the $6 \mathrm{MWT}$ has been reported in several studies $(15,21)$. In a study by Reesink et al. (25), 6MWT had significantly increased one year after PEA, reflecting clinical and hemodynamic improvement (25). However, the correlation of the 6MWT distances with the extent of disease in CTEPH has not been widely studied. In fact, the 6MWT distances did not correlate with the number of mismatched $\mathrm{Q}$ abnormalities in our study. Variance in walking distance can be explained by the individual's determinants such as age, sex, height, and weight on 6MWT.

\section{Study Limitations}

Following are the limitations of this study. First, this study was designed as a retrospective, single-center study. Nevertheless, our study has the largest number of patients whose diagnoses were proven by histopathology. Second, it is not rare to find matched V/Q abnormalities in patients with CTEPH that are seen late in the course of the disease. Hence, this problem might lead us to underestimate the extent of disease-related defects.

\section{Conclusion}

In conclusion, our study suggests that the extent of chronic thromboembolic disease revealed on V/Q SPECT/CT correlates with the preoperative hemodynamic parameters, thus predicting the severity and prognosis of the disease. Conversely, 6MWT was not found as a reliable indicator for the extent of the disease. Further studies are required in extended patient series to better represent the association between V/Q SPECT/CT Q defects with hemodynamic parameters and 6MWT in patients with $\mathrm{CTEPH}$. 


\section{Acknowledgement}

Authors would like to thank Asst. Prof. Dr. Tolga Sütlü for his help in the statistical analyses.

\section{Ethics}

Ethics Committee Approval: Marmara University Faculty of Medicine Clinical Studies Ethics Committee approval was also obtained (date: September 2020, no: 09.2020.852).

Informed Consent: Informed consents were obtained from the patients for conducting V/Q SPECT/CT examinations.

Peer-review: Externally and internally peer-reviewed.

\section{Authorship Contributions}

Surgical and Medical Practices: S.Ö., S.K., K.Ö., M.Y., S.T., F.Ş., T.Ö., S.I., H.T.T., B.M., T.Y.E., B.Y., Concept: S.Ö., S.K., T.Ö., B.Y., Design: S.Ö., S.K., T.Ö., B.Y., Data Collection or Processing: S.Ö., S.K., Analysis or Interpretation: S.Ö., S.K., Literature Search: S.Ö., S.K., Writing: S.Ö., S.K.

Conflict of Interest: No conflict of interest was declared by the authors.

Financial Disclosure: The authors declared that this study has received no financial support.

\section{References}

1. Jenkins D, Madani M, Fadel E, D'Armini AM, Mayer E. Pulmonary endarterectomy in the management of chronic thromboembolic pulmonary hypertension. Eur Respir Rev 2017;26:160111.

2. Pengo $V$, Lensing $A W$, Prins $M H$, Marchiori $A$, Davidson BL, Tiozzo $F$, Albanese P, Biasiolo A, Pegoraro C, lliceto S, Prandoni P; Thromboembolic Pulmonary Hypertension Study Group. Incidence of chronic thromboembolic pulmonary hypertension after pulmonary embolism. $\mathrm{N}$ Engl J Med 2004;350:2257-2264.

3. Fernandes T, Planquette $B$, Sanchez $O$, Morris T. From Acute to Chronic Thromboembolic Disease. Ann Am Thorac Soc 2016;13:207-214.

4. O'Connell C, Montani D, Savale L, Sitbon O, Parent F, Seferian A, Bulifon S, Fadel E, Mercier O, Mussot S, Fabre D, Dartevelle P, Humbert M, Simonneau G, Jaïs X. Chronic thromboembolic pulmonary hypertension. Presse Med 2015;44:409-416.

5. Galiè N, Humbert M, Vachiery JL, Gibbs S, Lang I, Torbicki A, Simonneau G, Peacock A, Vonk Noordegraaf A, Beghetti M, Ghofrani A, Gomez Sanchez MA, Hansmann G, Klepetko W, Lancellotti P, Matucci M, McDonagh T, Pierard LA, Trindade PT, Zompatori M, Hoeper M; ESC Scientific Document Group. 2015 ESC/ERS Guidelines for the diagnosis and treatment of pulmonary hypertension: The Joint Task Force for the Diagnosis and Treatment of Pulmonary Hypertension of the European Society of Cardiology (ESC) and the European Respiratory Society (ERS): Endorsed by: Association for European Paediatric and Congenital Cardiology (AEPC), International Society for Heart and Lung Transplantation (ISHLT). Eur Heart J 2016:37:67-119.

6. Renapurkar RD, Bolen MA, Shrikanthan S, Bullen J, Karim W, Primak A, Heresi GA. Comparative assessment of qualitative and quantitative perfusion with dual-energy $C T$ and planar and SPECT-CT V/Q scanning in patients with chronic thromboembolic pulmonary hypertension. Cardiovasc Diagn Ther 2018;8:414-422.
7. Lang IM, Madani M. Update on chronic thromboembolic pulmonary hypertension. Circulation 2014;130:508-518

8. Inami T, Kataoka M, Ando M, Fukuda K, Yoshino H, Satoh T. A new era of therapeutic strategies for chronic thromboembolic pulmonary hypertension by two different interventional therapies; pulmonary endarterectomy and percutaneous transluminal pulmonary angioplasty. PLoS One 2014;9:e94587.

9. Thistlethwaite PA, Kaneko K, Madani MM, Jamieson SW. Technique and outcomes of pulmonary endarterectomy surgery. Ann Thorac Cardiovasc Surg 2008;14:274-282.

10. Thistlethwaite PA, Kemp A, Du L, Madani MM, Jamieson SW. Outcomes of pulmonary endarterectomy for treatment of extreme thromboembolic pulmonary hypertension. J Thorac Cardiovasc Surg 2006;131:307-313.

11. Yanartas M, Kalkan ME, Arslan A, Tas SG, Koksal C, Bekiroglu N, Yildizeli B. Neutrophil/Lymphocyte Ratio Can Predict Postoperative Mortality in Patients with Chronic Thromboembolic Pulmonary Hypertension. Ann Thorac Cardiovasc Surg 2015;21:229-235.

12. Sunbul M, Kivrak T, Durmus E, Yildizeli B, Mutlu B. Evaluation of right and left heart mechanics in patients with chronic thromboembolic pulmonary hypertension before and after pulmonary thromboendarterectomy. Int J Cardiovasc Imaging. 2015;31:1159-1167.

13. Bajc $M$, Schümichen $C$, Grüning $T$, Lindqvist $A$, Le Roux PY, Alatri $A$, Bauer RW, Dilic M, Neilly B, Verberne HJ, Delgado Bolton RC, Jonson B. EANM guideline for ventilation/perfusion single-photon emission computed tomography (SPECT) for diagnosis of pulmonary embolism and beyond. Eur J Nucl Med Mol Imaging 2019;46:2429-2451.

14. Boyden EA. Segmental Anatomy of the Lungs. Blakiston Division. McGraw-Hill Co. New York, 1955.

15. Boxer R, Kleppinger A, Ahmad A, Annis K, Hager D, Kenny A. The 6-minute walk is associated with frailty and predicts mortality in older adults with heart failure. Congest Heart Fail 2010;16:208-213.

16. ATS Committee on Proficiency Standards for Clinical Pulmonary Function Laboratories. ATS statement: guidelines for the six-minute walk test. Am J Respir Crit Care Med 2002;166:111-117.

17. Yıldızeli B, Taş S, Yanartaş M, Kaymaz C, Mutlu B, Karakurt S, Altınay E, Eldem B, Ermerak NO, Batırel HF, Koçak T, Bekiroğlu N, Yüksel M, Sunar $H$. Pulmonary endarterectomy for chronic thrombo-embolic pulmonary hypertension: an institutional experience. Eur J Cardiothorac Surg 2013;44:219-227

18. Humbert M, Monti G, Brenot F, Sitbon O, Portier A, Grangeot-Keros L, Duroux P, Galanaud P, Simonneau G, Emilie D. Increased interleukin-1 and interleukin-6 serum concentrations in severe primary pulmonary hypertension. Am J Respir Crit Care Med 1995;151:1628-1631.

19. Dartevelle $P$, Fadel $E$, Mussot $S$, Chapelier $A$, Hervé $P$, de Perrot $M$, Cerrina J, Ladurie FL, Lehouerou D, Humbert M, Sitbon O, Simonneau G. Chronic thromboembolic pulmonary hypertension. Eur Respir J 2004;23:637648.

20. Sandoval J, Bauerle O, Palomar A, Gómez A, Martínez-Guerra ML, Beltrán M, Guerrero ML. Survival in primary pulmonary hypertension. Validation of a prognostic equation. Circulation 1994;89:1733-1744.

21. Saouti N, de Man F, Westerhof N, Boonstra A, Twisk J, Postmus PE, Vonk Noordegraaf A. Predictors of mortality in inoperable chronic thromboembolic pulmonary hypertension. Respir Med 2009;103:10131019.

22. Leone MB, Giannotta M, Palazzini M, Cefarelli M, Martìn Suàrez S, Gotti E, Bacchi Reggiani ML, Zompatori M, Galiè N. A new CT-score as index of hemodynamic changes in patients with chronic thromboembolic pulmonary hypertension. Radiol Med 2017;122:495-504.

23. Fukuchi K, Hayashida K, Nakanishi N, Inubushi M, Kyotani S, Nagaya N, Ishida Y. Quantitative analysis of lung perfusion in patients with primary pulmonary hypertension. J Nucl Med 2002;43:757-761. 
24. Derlin T, Kelting C, Hueper K, Weiberg D, Meyer K, Olsson KM, Thackeray JT, Welte T, Bengel FM, Hoeper MM. Quantitation of Perfused Lung Volume Using Hybrid SPECT/CT Allows Refining the Assessment of Lung Perfusion and Estimating Disease Extent in Chronic Thromboembolic Pulmonary Hypertension. Clin Nucl Med 2018;43:170-177.
25. Reesink HJ, van der Plas MN, Verhey NE, van Steenwijk RP, Kloek JJ, Bresser P. Six-minute walk distance as parameter of functional outcome after pulmonary endarterectomy for chronic thromboembolic pulmonary hypertension. J Thorac Cardiovasc Surg 2007;133:510-516. 